\title{
Corak Taburan Ruang-Masa Semut (Hymenoptera: Formicidae) di Ekosistem Sawit, Endau Rompin, Pahang
}

(Spatio-Temporal Pattern of Ants (Hymenoptera: Formicidae) in Endau Rompin Oil Palm Ecosystem, Pahang)

\author{
WAN ZAKHIR WAN NAZRI, DZULHELMI MUHAMMAD NASIR, NUR-ATHIRAH ABDULLAH, FARAH NADIAH ROSLI,
} BAKHTIAR EFFENDI YAHYA \& FASZLY RAHIM*

\begin{abstract}
ABSTRAK
Kajian ini dijalankan bagi mengetahui corak taburan ruang-masa semut (Hymenoptera: Formicidae) dan memahami ekologi ruang semut di ekosistem sawit di Endau Rompin, Pahang. Persampelan dijalankan selama empat bulan berturutturut di tiga jenis tanah iaitu tanah liat (A1 \& A2), tanah gambut dalam (B1 \& B2) dan tanah gambut cetek (C1 \& C2). Kaedah perangkap lubang digunakan bagi mensampel semut yang mencari makanan di atas tanah. Sejumlah 3,968 individu semut berjaya diperoleh, mewakili 13 genus dalam empat subfamili. Anoplolepis mencatatkan bilangan individu paling melimpah iaitu sebanyak 1,692 individu (45.75\%) diikuti dengan Pheidole (862 individu; 23.31\%) dan Paratrechina (228 individu; 6.17\%). Dalam tanah liat, Anoplolepis ialah genus yang paling melimpah manakala bagi tanah gambut dalam dan cetek, Pheidole adalah genus yang paling melimpah berbanding genus yang lain. Ujian Khi kuasa-dua (dua hala) mengenal pasti perbezaan yang signifikan $(\mathrm{p}<0.05)$ bagi komposisi lapan genus iaitu Anoplolepis, Oecophylla, Paratrechina, Odontomachus, Ponera, Crematogaster, Pheidole, dan Tetramorium dalam kombinasi tanah, bulan dan genus. Bagi corak taburan ruang-masa pula, Formicinae secara keseluruhannya menunjukkan corak taburan ruang yang berkelompok (Ia > 1; p <0.05) manakala bagi Ponerinae, Myrmicinae dan Aenictinae, corak taburan ruang-masa adalah berbentuk rawak (Ia $\leq 1$; p > 0.05). Corak taburan ruang-masa setempat bagi subfamili semut adalah sangat dinamik dengan perubahan corak kelompok dan luang yang berbeza pada bulan yang berlainan. Gambaran awal corak taburan ruang-masa setempat bagi semut di ekosistem sawit yang diperoleh dalam kajian ini menunjukkan hubung kait ekologi dan lakuan beberapa genus walau pun secara kolektifnya dicerap pada peringkat subfamili. Kajian lanjut bagi melihat asosiasi ruang-masa antara subfamili dirasakan perlu bagi memperjelaskan lagi ekologi lakuan dan interaksi dalam kalangan komuniti berfungsi semut.
\end{abstract}

Kata kunci: Corak ruang-masa; ekosistem sawit; Formicidae; pencari makan atas tanah

\section{ABSTRACT}

This study was conducted to determine the spatio-temporal pattern of ants (Hymenoptera: Formicidae) in order to understand the ecology of ants in palm oil ecosystem at Endau Rompin, Pahang. Sampling was carried out for four consecutive months on three types of soils, i.e. clay (plots A1 \& A2), deep peat (plots B1 \& B2) and shallow peat (plots C1 \& C2). Pitfall trapping was used as it is suitable for ants that forages on the ground. A total of 3,968 individuals were captured consisting of 13 genera in four subfamilies. Anoplolepis was the most abundant with 1,692 individuals (45.75\%) followed by Pheidole (862 individuals; $23: 31 \%$ ) and Paratrechina (228 individuals; $6.17 \%$ ). In clay, Anoplolepis is the most abundant meanwhile in deep and shallow peat, Pheidole have the highest number of individuals compared to other genera. Two-way Chi-squared analysis identified that there were significant differences $(\mathrm{p}<0.05)$ in the compositions amongst the eight genera (Anoplolepis, Oecophylla, Paratrechina, Odontomachus, Ponera, Crematogaster, Pheidole, and Tetramorium) with soil, months and genus combined. As for the spatio-temporal distribution pattern, Formicinae showed in overall clustered patterns $(I a>1 ; \mathrm{p}<0.05)$ while Ponerinae, Myrmicinae and Aenictinae showed a randomised distribution pattern (Ia $\leq 1 ; \mathrm{p}>0.05)$. Local spatio-temporal pattern for the subfamilies was dynamic with patchy patterns and gaps varied across months. The spatio-temporal pattern amongst ants observed in this study showed a strong relationship between the ecology and the behaviour of some ant genera despite observation was done at the subfamily level. Further study to identify the spatio-temporal associations amongst subfamilies is needed to elucidate behavioural ecology of ants and interactions within the diferrent functional groups.

Keywords: Above-ground foragers; Formicidae; oil palm ecosystems; spatio-temporal distribution

\section{PENGENALAN}

Semut (Hymenoptera: Formicidae) adalah serangga eusosial yang mempunyai bilangan genus serta spesies yang lebih banyak berbanding serangga eusosial lain seperti lebah, tebuan dan anai-anai (Leonhardt et al. 2016). Semut dikenal pasti sebagai serangga eusosial apabila ia mempunyai 
struktur sosial yang terdiri daripada ratu koloni dan juga pekerja. Ratu koloni adalah individu betina yang subur untuk menghasilkan telur bagi kelansungan spesies. Pekerja pula adalah individu lain daripada spesies sama yang bekerjasama dalam proses mencari makanan dan juga penjagaan telur serta larva. Terdapat sekurang-kurangnya dua generasi semut pekerja bagi memastikan koloni sentiasa stabil (Collingwood et al.2011). Sifat ini telah menjadikan semut sebagai haiwan majoriti di dalam sesuatu habitat contohnya ladang kelapa sawit (Lutinski et al. 2017). Justeru, ini menjadikannya calon yang sesuai sebagai penunjuk biologi ekosistem dan sekaligus menekankan kepentingan kajian ekologi kumpulan serangga tersebut.

Terdapat pelbagai kajian lepas dilakukan ke atas corak taburan komuniti semut. Ini termasuk telahan corak kedominan tingkah laku semut yang asli, pemuliharaan biologi dan pemahaman biogeografi semut (Dunn et al. 2007; Munyai \& Foord 2015). Kajian ini menekankan corak taburan ruang-masa semut di kawasan tanaman ladang kelapa sawit di Endau Rompin, Pahang, Malaysia. Secara definisi, corak taburan ruang disifatkan sebagai pola kepelbagaian subjek di lokasi berbeza yang dipengaruhi pelbagai faktor seperti cuaca, topografi, jenis tanah, suhu air, sumber makanan dan rintangan yang terdapat di lokasi tersebut (Denno et al. 2002; Wardhaugh 2014). Sementara corak taburan masa pula bermaksud pola kepelbagaian subjek pada tempoh masa yang berbeza seperti contoh, siang dan malam atau musim berbeza. Gabungan corak taburan ruang-masa menjadi paksi asas dalam menentukan bentuk sistem ekologi dan mengawal taburan spesies di persekitaran (Wolkovich et al. 2014).

Tanaman sawit merupakan sumber ekonomi komoditi utama Malaysia dengan eksport mencecah sebanyak 16.05 juta tan pada tahun 2016 (MPOB 2017). Selain itu, produk minyak sawit juga telah dicatatkan sebagai sumber tenaga boleh baharu pada masa hadapan dan pelbagai kajian mendalam tentangnya sedang dilakukan (Loh 2017; Mohammed et al. 2011; Sulaiman et al. 2011). Pengetahuan mengenai ekosistem dan kepelbagaian biologi di ladang-ladang kelapa sawit dapat membantu dalam usaha melestarikan sumber alam di kawasan perlandangan (Foster at al. 2011). Semut membawa kepentingan yang pelbagai kepada ekosistem sawit. Del Toro et al.(2012) telah membuat ulasan kritis berkaitan manfaat serta kemudaratan yang dibawa semut terhadap ekosistem. Beliau mendapati semut memainkan peranan yang penting dalam mengawal atur dan menyangga sistem ekologi. Contohnya sebagai agen penyebaran biji benih (myrmecochory), agen pendebunga, agen kawalan biologi dan agen penunjuk biologi di samping memoroskan tanah untuk tanaman dan mengurai organisma menjadi sumber nutrien (Del Toro et al. 2012). Kajian Stephens dan Wagner (2006) menggunakan semut sebagai agen penunjuk biologi dalam mengesan tahap kesihatan hutan Arizona yang telah mengalami peristiwa kebakaran tidak terkawal. Kawasan hutan dirawat berdasarkan perbandingan corak taburan serta kepelbagaian semut antara kawasan hutan terbakar dengan kawasan hutan yang tidak terkesan oleh pembakaran.
Secara keseluruhan, pengetahuan asas mengenai corak taburan ruang-masa semut di ekosistem sawit boleh memberi dua manfaat kepada pengusaha tanaman iaitu membantu menentukan jenis tanah yang sesuai sebagai habitat dan musim yang optimum bagi aktiviti pengkolonian. Pengetahuan ini boleh dikaitkan dengan hasil tanaman pada ruang-masa tersebut dan seterusnya membuktikan kepentingan semut terhadap tanaman sawit. Selain itu, pengusaha tanaman juga boleh mempertimbangkan penggunaan semut sebagai agen pelbagai kegunaan di ladang atas dasar ia mudah diperoleh dan koloninya yang besar. Namun, kajian yang lebih spesifik perlu dilakukan sebelum sebarang aplikasi dijalankan.

\section{BAHAN DAN KAEDAH}

\section{TAPAK KAJIAN}

Kajian ini dijalankan di ladang sawit Endau-Rompin (2²0'25.81”N, 103³4'40.56”E) milik YP Plantation Holdings Sdn Bhd. Ladang sawit yang berkeluasan 3,654 hektar ini terletak dalam radius $15 \mathrm{~km}$ dari Pekan Tanjung Gemuk, Kuala Rompin, Pahang dan Padang Endau Mersing, Johor dan bersempadanan dengan Taman Negara Endau-Rompin di bahagian baratnya (Faszly 2008).

Ladang sawit ini pada asalnya merupakan hutan paya gambut yang telah mengalami pembalakan dan kelapa sawit kemudian ditanam seawal tahun 1995. Terdapat tiga jenis tanah utama iaitu tanah gambut dalam, tanah gambut cetek dan tanah liat. Kebiasaannya, tanah gambut dalam dan cetek berada pada bahagian sempadan ladang sawit ini. Tanah gambut dalam boleh mencecah melebihi enam inci ke dalam. Tanah liat pula lebih tertumpu di pinggir bahagian barat laut dan tenggara ladang, dan kebanyakannya dijumpai di bahagian pinggiran sungai yang berada di sempadan ladang. Terdapat parit atau longkang yang dibina mengikut grid di seluruh kawasan ladang ini untuk tujuan saliran dan pengawalan air ketika musim kering dan musim banjir.

\section{KAEDAH PERSAMPELAN}

Persampelan dijalankan sekali setiap bulan selama empat bulan berturut-turut antara Disember 2011 dan Mac 2012. Enam plot telah dipilih dengan setiap dua plot mewakili persampelan bagi jenis tanah berbeza iaitu pada tanah liat (A1 dan A2), tanah gambut dalam (B1 dan B2) dan tanah gambut cetek (C1 dan C2) (Rajah 1). Setiap plot mempunyai keluasan sebanyak lebih kurang empat hektar. Persampelan dilakukan dengan menggunakan kaedah perangkap lubang untuk menangkap serangga terrestrial yang aktif pada permukaan tanah (Ellison et al. 2011). Perangkap lubang yang terdiri daripada gelas plastik $(12 \mathrm{~cm}$ diameter $\times$ kedalaman $8 \mathrm{~cm}$ ) diletakkan di dalam lubang sehingga permukaan gelas separas dengan permukaan tanah. Air sabun yang dicampurkan dengan alkohol $70 \%$ diletakkan di dalam gelas plastik. Sejumlah 70 unit perangkap lubang ini ditempatkan di dalam grid 7 
$\times 10$ pada setiap plot. Jarak antara setiap perangkap lubang adalah 30 meter. Jumlah perangkap bagi keenam-enam plot ini adalah sebanyak 420 perangkap. Serangga yang terjatuh dan terperangkap ke dalam perangkap lubang kemudiannya dikutip selepas 24 jam. Hasil tangkapan diisihkan dan diawet dalam vail berisi alkohol $70 \%$ untuk disimpan.

\section{PENGECAMAN SPESIES}

Spesimen yang telah diisih, diawetkan dengan kaedah pengawetan basah. Kemudian, spesimen ini diasingkan mengikut subfamili dan dicamkan sehingga ke peringkat genus dengan menggunakan rujukan Bolton (1995) dan Hashimoto (2003) dan pangkalan data atas talian melalui capaian http://www.antbase.net. Pengecaman spesimen turut dilakukan dengan membandingkan spesimen yang telah dikenal pasti oleh pakar yang terdapat di dalam koleksi Pusat Sistematik Serangga, Universiti Kebangsaan Malaysia. Spesimen yang telah dicam dilabel lokasi, tarikh dan nama pengumpul, dan disimpan sebagai koleksi Pusat Sistematik Serangga, Universiti Kebangsaan Malaysia untuk rujukan masa hadapan.

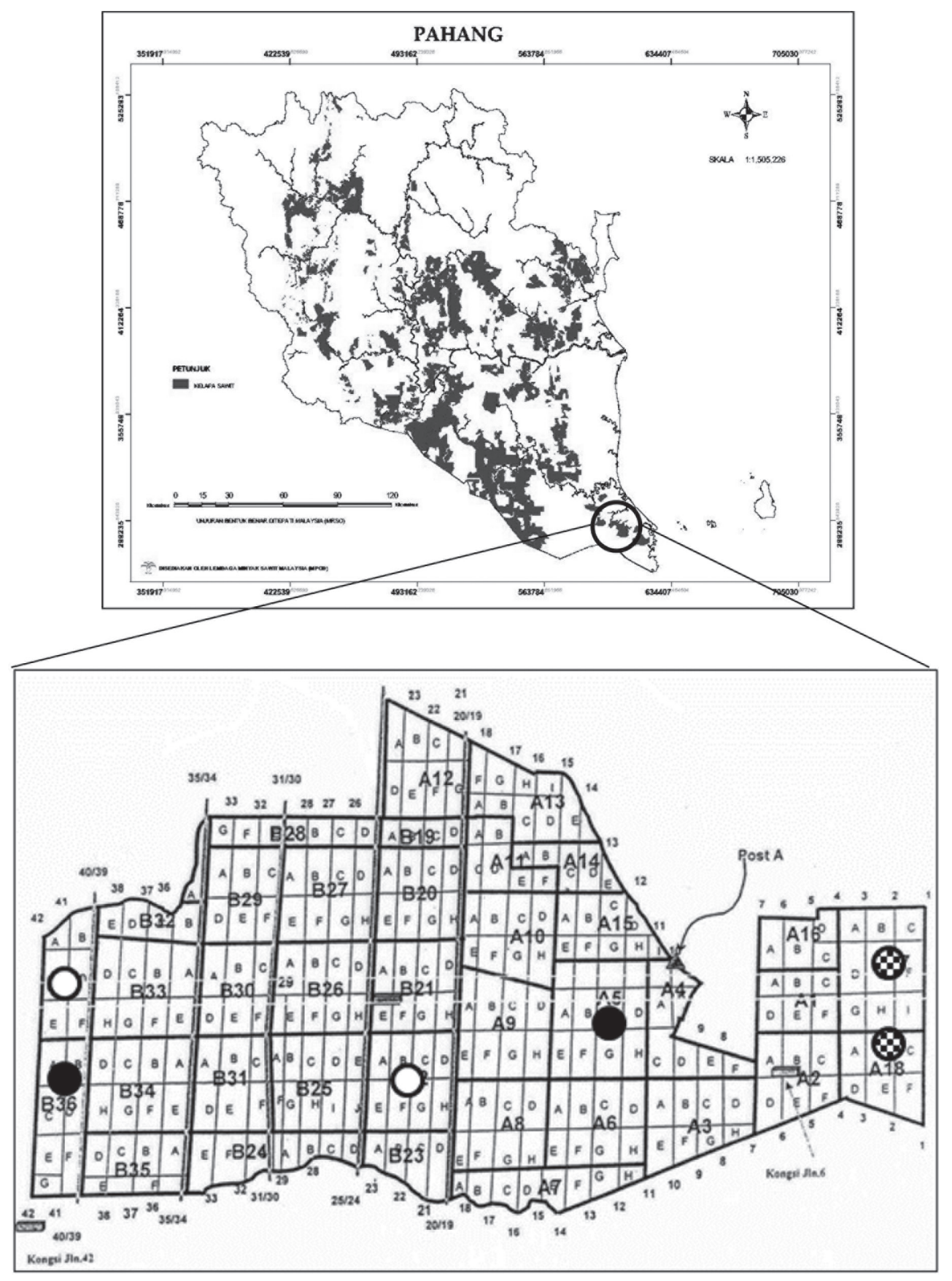

RAJAH 1. Tapak kajian dan kawasan persampelan di ladang sawit Endau-Rompin. Tanah liat (A1 dan A2) (\&); Tanah gambut dalam (B1 dan B2) (O); Tanah gambut cetek (C1 dan C2) 


\section{ANALISIS DATA}

Ujian khi kuasa-dua $\left(\chi^{2}\right)$ dua-hala digunakan untuk membandingkan komposisi semut bagi menentukan perbezaan antara setiap subfamili dan genus pada tiga jenis tanah yang berbeza. Analisis ini dijalankan menggunakan perisian komputer MINITAB (Minitab Inc. 2006).

Corak taburan ruang-masa bagi setiap subfamili semut dianalisis melalui kaedah yang telah dibangunkan oleh Perry et al. (2002) menggunakan indeks jarak atau singkatannya (SADIE). SADIE dijana bagi mendapatkan nilai Indeks Agregasi (Ia) untuk keseluruhan plot persampelan. Bagi corak taburan rawak, nilai indeks yang dijangka adalah Ia = 1 manakala, nilai yang lebih besar Ia $>1$ menunjukkan corak agregasi (pengelompokan menumpuk). Dalam analisis ini, terdapat nilai untuk menentukan corak nilai tompokan setempat dan nilai luang yang terdapat pada plot persampelan. Min Vi (min Vi) menentukan nilai tompokan setempat manakala min $\mathrm{Vj}(\min \mathrm{Vj}$ ) menentukan nilai luang yang terdapat pada plot. Nilai p bagi Indeks Agregasi, Ia, min Vi dan min $\mathrm{Vj}$ menentukan samada nilai tersebut adalah signifikan ataupun tidak bagi setiap plot persampelan. Nilai $p<0.05$ menunjukkan terdapat pengelompokan signifikan bagi nilai yang diperoleh. Analisis corak taburan ruang-masa ini hanya dapat dicapai pada peringkat subfamili sahaja kerana pada peringkat yang lebih rendah bilangan individu adalah terlalu kecil menyebabkan pengelompokan yang signifikan tidak terhasil. Bilangan semut yang dapat dicerap pada setiap perangkap pada setiap bulan dipetakan mengikut grid $7 \times 10$ bagi setiap plot dan dianalisis menggunakan perisian SADIEshell (Conrad \& Rothamsted 2001).
Pemetaan kontur dan peta pasca berkelas digunakan dalam memetakan corak taburan ruang bagi setiap subfamili semut setelah indeks SADIE diperoleh. Peta kontur diunjurkan berdasarkan kaedah pengiraan jiran terdekat yang kemudiannya dikrigkan menggunakan perisian SURFER 8 (Golden Software Inc. 2002). Kawasan yang mempunyai bilangan individu yang melebihi lima diwarnakan dengan warna yang lebih gelap manakala peta pasca berkelas pula diplot berdasarkan bilangan individu di setiap titik persampelan.

\section{KEPUTUSAN DAN PERBINCANGAN}

Sejumlah 3,698 individu semut yang mewakili 13 genera dalam empat subfamili telah diperoleh hasil daripada persampelan (Jadual 1). Berdasarkan hasil tersebut, individu yang mencatatkan bilangan paling tinggi adalah daripada genus Anoplolepis (1,692 individu; 45.75\%), manakala bilangan yang paling rendah adalah daripada genus Camponotus (20 individu; 0.54\%). Pada masa yang sama, terdapat 52 individu $(1.41 \%)$ semut yang tidak berjaya dikenal pasti.

Anoplolepis merupakan genus yang paling dominan kerana genus ini merupakan satu spesies yang muncul di setiap lokasi persampelan. Koloni Anoplolepis yang sering mempunyai hubungan koloni antara satu sama lain dan mempamerkan tahap pencerobohan antara koloni yang rendah merupakan ciri utama dominasi spesies ini di setiap ekosistem (Hölldobler \& Wilson 1990). Genus ini dikenal pasti sebagai semut yang dominan di ekosistem sawit di Sabah dan Semenanjung Malaysia

JADUAL 1. Bilangan individu semut mengikut genus dan subfamili berdasarkan empat kali persampelan dari Disember 2011 hingga Mac 2012 menggunakan perangkap lubang di LER

\begin{tabular}{|c|c|c|c|c|c|c|c|}
\hline \multirow[b]{2}{*}{ Subfamili } & \multirow[b]{2}{*}{ Genus } & \multicolumn{4}{|c|}{ Bulan } & \multirow[b]{2}{*}{ Jumlah } & \multirow[b]{2}{*}{ Peratus $\%$} \\
\hline & & $\begin{array}{c}\text { Disember } \\
\text { (DIS) }\end{array}$ & $\begin{array}{c}\text { Januari } \\
\text { (JAN) }\end{array}$ & $\begin{array}{c}\text { Februari } \\
(\text { FEB })\end{array}$ & $\begin{array}{c}\text { Mac } \\
(\mathrm{MAC})\end{array}$ & & \\
\hline \multirow[t]{4}{*}{ Formicinae (FORM) } & Anoplolepis & 246 & 163 & 1059 & 224 & 1692 & 45.75 \\
\hline & Oecophylla & 31 & 11 & 44 & 32 & 118 & 3.19 \\
\hline & Paratrechina & 31 & 21 & 116 & 60 & 228 & 6.17 \\
\hline & Camponotus & 3 & 3 & 5 & 9 & 20 & 0.54 \\
\hline \multirow[t]{4}{*}{ Ponerinae (PONE) } & Odontomachus & 12 & 23 & 54 & 17 & 106 & 2.87 \\
\hline & Odontoponera & 12 & 8 & 21 & 31 & 72 & 1.95 \\
\hline & Ponera & 21 & 23 & 89 & 38 & 171 & 4.62 \\
\hline & Leptogenys & 2 & 3 & 13 & 8 & 26 & 0.7 \\
\hline \multirow[t]{4}{*}{ Myrmicinae (MYRM) } & Crematogaster & 12 & 6 & 5 & 5 & 28 & 0.76 \\
\hline & Pheidole & 122 & 158 & 475 & 107 & 862 & 23.31 \\
\hline & Proatta & 6 & 31 & 47 & 10 & 94 & 2.54 \\
\hline & Tetramorium & 23 & 43 & 66 & 31 & 163 & 4.41 \\
\hline Aenictinae (AENI) & Aenictus & 12 & 5 & 45 & 4 & 66 & 1.78 \\
\hline Tidak dapat dikenal pasti & & 5 & 6 & 26 & 15 & 52 & 1.41 \\
\hline Jumlah & & & & & & 3698 & 100 \\
\hline
\end{tabular}


(Pfeiffer et al. 2008). Ia juga merupakan semut invasif dan telah didokumenkan sebagai semut yang paling dominan di semua habitat terganggu di seluruh dunia (Bos et al. 2008). Walau bagaimanapun, Anoplolepis dianggap sebagai spesies yang memberi manfaat dengan mengurangkan bilangan serangga perosak pada tanaman kerana sifatnya yang bertindak sebagai pemangsa (Shattuck 2000). Genus Anoplolepis mempunyai struktur organisasi sosial yang baik kerana terdapat beberapa sarang yang setiap daripadanya mempunyai permaisuri yang berbeza namun bekerjasama untuk mendapatkan makanan, sumber dan perlindungan. Organisasi sosial Anoplolepis ini mengelakkan pencerobohan terhadap koloninya oleh koloni lain dan ini akan memperluaskan lagi tanah jajahan mereka (Errard et al. 2005; Hoffmann \& Hagedorn 2014). Genus ini memaparkan ciri superkoloni dengan cara berhubung antara satu koloni dengan yang lain (Drescher et al. 2007). Sarang yang saling berhubung ini menunjukkan bahawa tiada sempadan antara koloni (Giraud et al. 2002). Ini jelas menunjukkan bahawa genus Anoplolepis ini mempunyai kawasan jajahan yang luas untuk mencari makanan dan membuat sarang sebagai habitat.

Formicinae pula merupakan subfamili yang paling tinggi dan dominan di kawasan tanah liat kerana subfamili ini sentiasa diperoleh pada setiap bulan persampelan (Rajah 2). Struktur koloninya yang sentiasa berubah merupakan salah satu penyumbang kepada penguasaan habitat oleh Fomicinae ini. Pada masa yang sama, Myrmicinae mencatatkan bilangan yang tertinggi dan dominan pada tanah gambut dalam dan cetek dan diperoleh pada setiap bulan persampelan. Kejayaan ekologi bagi subfamili ini

(a)

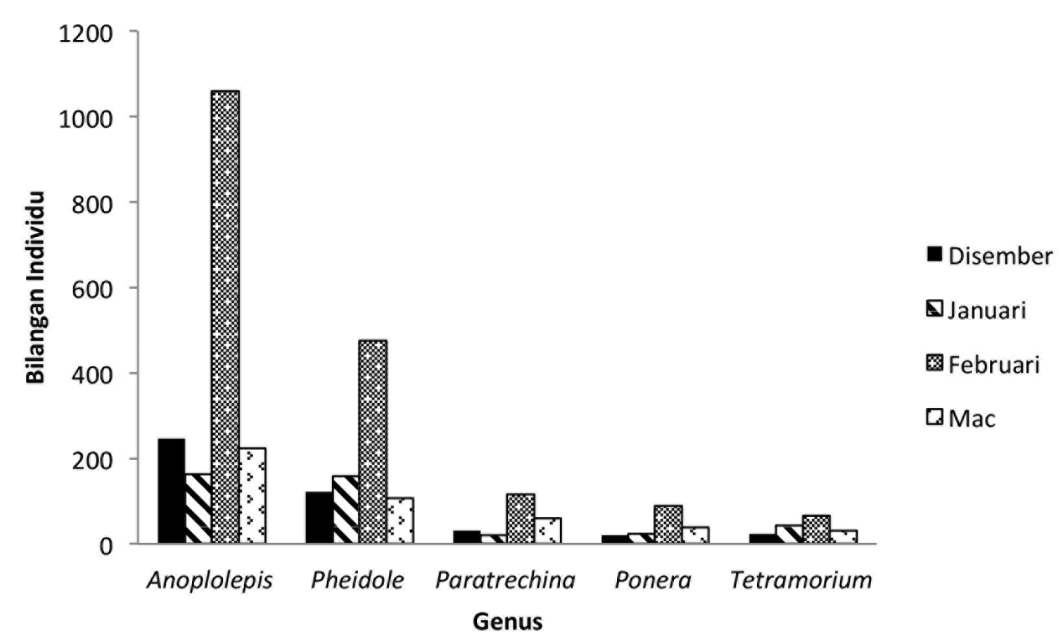

(b)

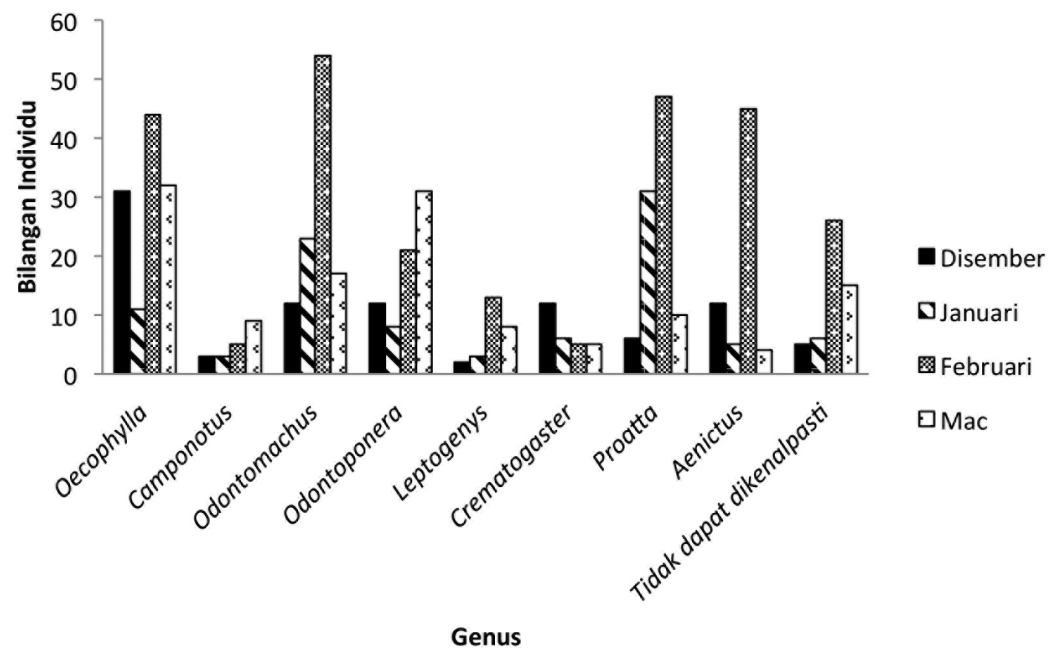

RAJAH 2. (a) dan (b): Bilangan individu bagi genus semut berdasarkan empat kali persampelan dari Disember 2011 hingga Mac 2012 menggunakan perangkap lubang di LER 
bergantung kepada morfologi pekerja untuk menyesuaikan diri dengan keadaan persekitaran bagi mendapatkan makanan (Davidson et al. 2004).

Anoplolepis dan Pheidole adalah merupakan genus yang dominan di kesemua jenis tanah kerana munculnya hampir pada setiap bulan persampelan. Anoplolepis merupakan genus yang banyak didapati di kebanyakan kawasan manakala Pheidole merupakan genus yang biasa dijumpai sebagai semut yang aktif dalam membina sarang daripada tanah dan keluar berburu untuk mendapatkan makanan (Shattuck 2000).

Komposisi semut pada kesemua plot persampelan menunjukkan terdapat perbezaan yang signifikan bagi kombinasi tanah dan bulan $\left(\chi^{2}=106.110, \mathrm{dk}=6, p<0.05\right)$, tanah dan genus $\left(\chi^{2}=1892.941, \mathrm{dk}=24, p<0.05\right)$ dan bulan dan genus $\left(\chi^{2}=276.763, \mathrm{dk}=36, p<0.05\right)$. Namun begitu, genus Aenictus, Camponotus, Leptogenys, Odontoponera dan Proatta tidak menunjukkan sebarang perbezaan yang signifikan bagi komposisi pada setiap bulan pada tanah yang berbeza. Manakala, terdapat perbezaan yang signifikan antara perangkap yang diperoleh pada setiap bulan pada tanah yang berbeza bagi genus Anoplolepis $\left(\chi^{2}=222.410, \mathrm{dk}=6, p<0.05\right)$, Crematogaster $\left(\chi^{2}=\right.$ $19.405, \mathrm{dk}=6, p<0.05)$, Odontomachus $\left(\chi^{2}=15.065, \mathrm{dk}\right.$ $=6, p<0.05)$, Oecophylla $\left(\chi^{2}=10.284, \mathrm{dk}=6, p<0.05\right)$, Paratrechina $\left(\chi^{2}=18.999, \mathrm{dk}=6, p<0.05\right)$, Pheidole $\left(\chi^{2}\right.$ a)

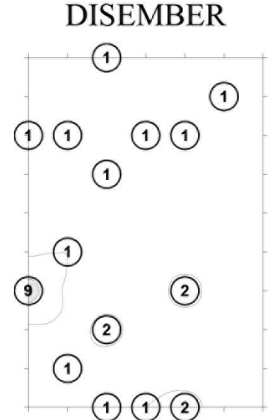

b)

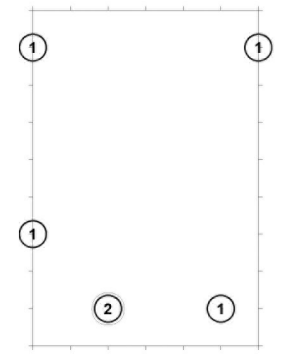

c)

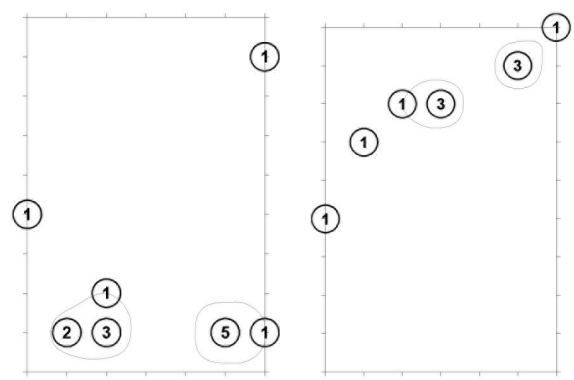

d)

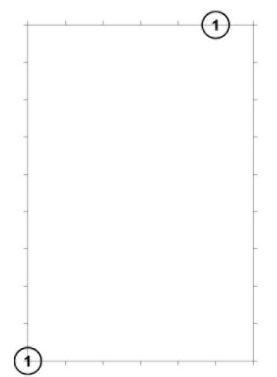

JANUARI
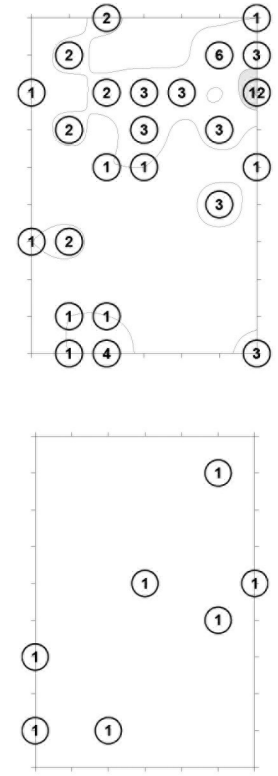

MAC

(1) (2) (3) (1) (1) (2) (4)

(1) (3) (3)

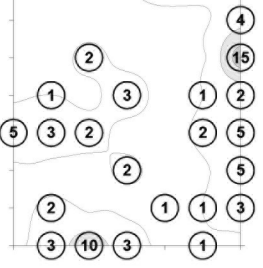

(2) (2) (1) (3) (3)
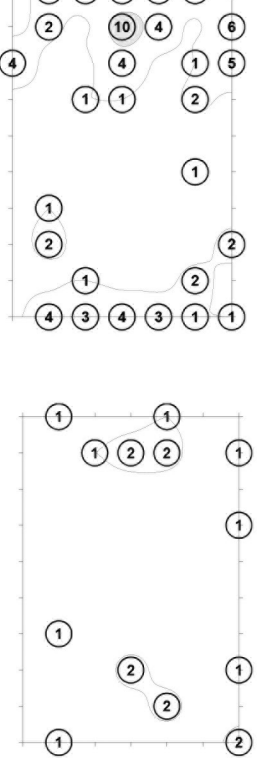
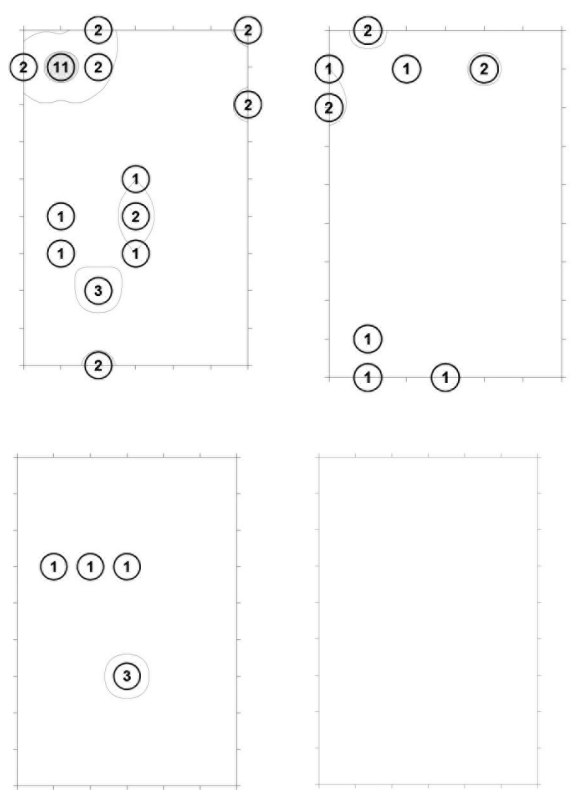

RAJAH 3. Corak taburan ruang-masa di plot A1 (tanah liat) bagi a) Formicinae; b) Ponerinae; c) Myrmicinae; dan d) Aenictinae 
$=79.537, \mathrm{dk}=6, p<0.05)$, Ponera $\left(\chi^{2}=18.290, \mathrm{dk}=6\right.$, $p<0.05)$ dan Tetramorium $\left(\chi^{2}=27.345, \mathrm{dk}=6, p<0.05\right)$.

\section{CORAK TABURAN RUANG-MASA SUBFAMILI SEMUT DALAM PLOT}

Corak taburan ruang-masa subfamili semut di dalam setiap plot ditunjukkan di dalam Rajah 3 hingga 8 .

Formicidae Pada Plot A1, Formicidae menunjukkan corak taburan yang rawak dan berkelompok. Pengelompokan setempat yang sangat nyata $(\mathrm{Vi}=1.282 ; p<0.05)$ dan luang yang signifikan $(\mathrm{Vj}=-1.285 ; p<0.05)$ antara kelompok terlihat dalam plot persampelan. Pada Plot A2 pula, corak taburannya adalah secara berkelompok dengan pengelompokan setempat yang nyata $(\mathrm{Vi}>1 ; p<0.05)$ dan luang persampelan juga adalah signifikan $(\mathrm{Vj}>1 ; p<0.05)$. Pada Plot B1, Formicidae menunjukkan corak taburan yang rawak dan juga berkelompok. Pengelompokan setempat yang ditunjukkan adalah signifikan $(\mathrm{Vi}>1 ; p<0.05)$ dan luang adalah nyata $(\mathrm{Vi}>1 ; p<0.05)$. Di Plot B2 pula, corak taburannya lebih kepada rawak $(\mathrm{Ia}=1.251)$ berbanding secara berkelompok. Hal ini menunjukkan corak taburan secara berkelompok adalah tidak signifikan $(p>0.05)$. Di Plot $\mathrm{C} 1$ dan Plot $\mathrm{C} 2$, Formicidae telah menunjukkan corak taburan secara rawak (Ia $\leq 1)$. a)

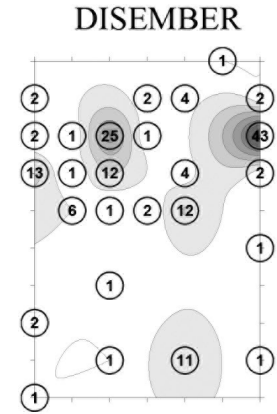

b)

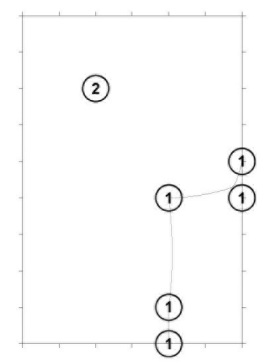

c)

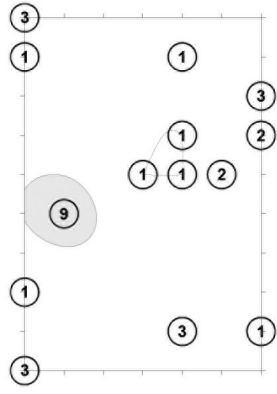

d)

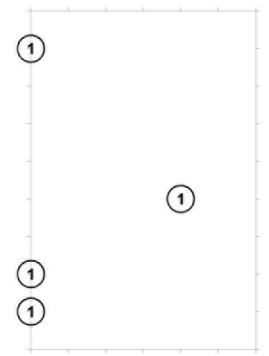

JANUARI

(1) (3)

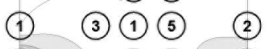
(24)
(5) (4) (15)

(5) (3) (7)

(1)
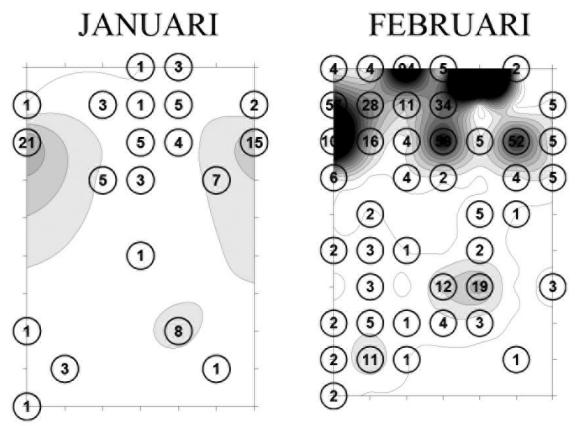

(2)

(5) (1)

(2) (3) (1) (2)

(3) (12) (19)

(2) (5) (1) (4) (3)

(2) (11) (1)

(2)

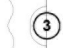

(3)
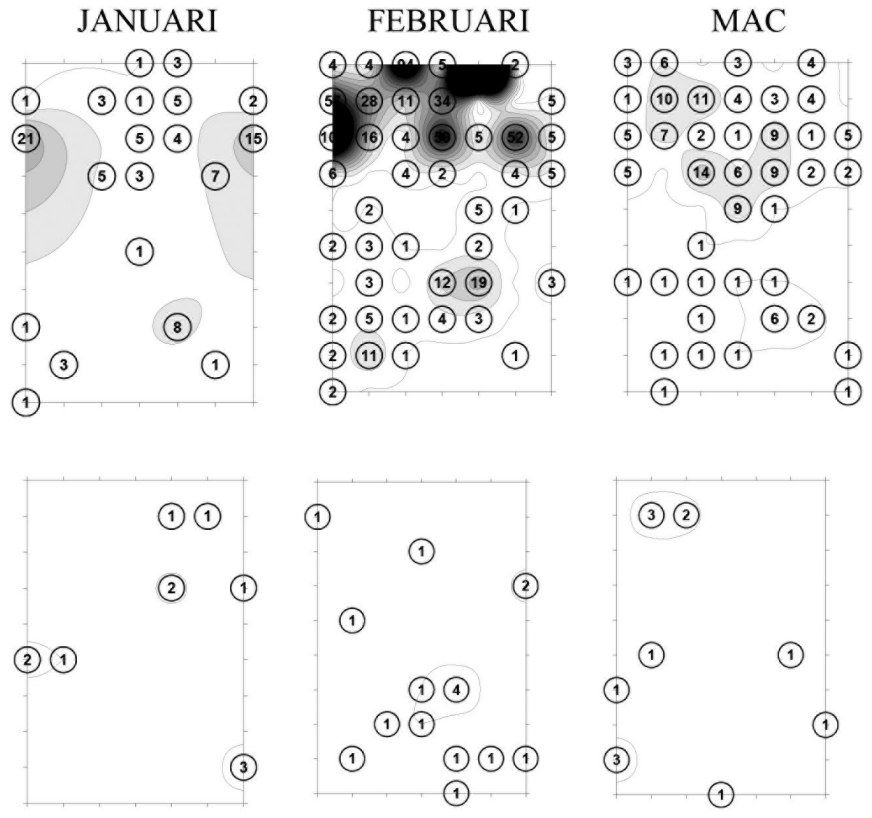
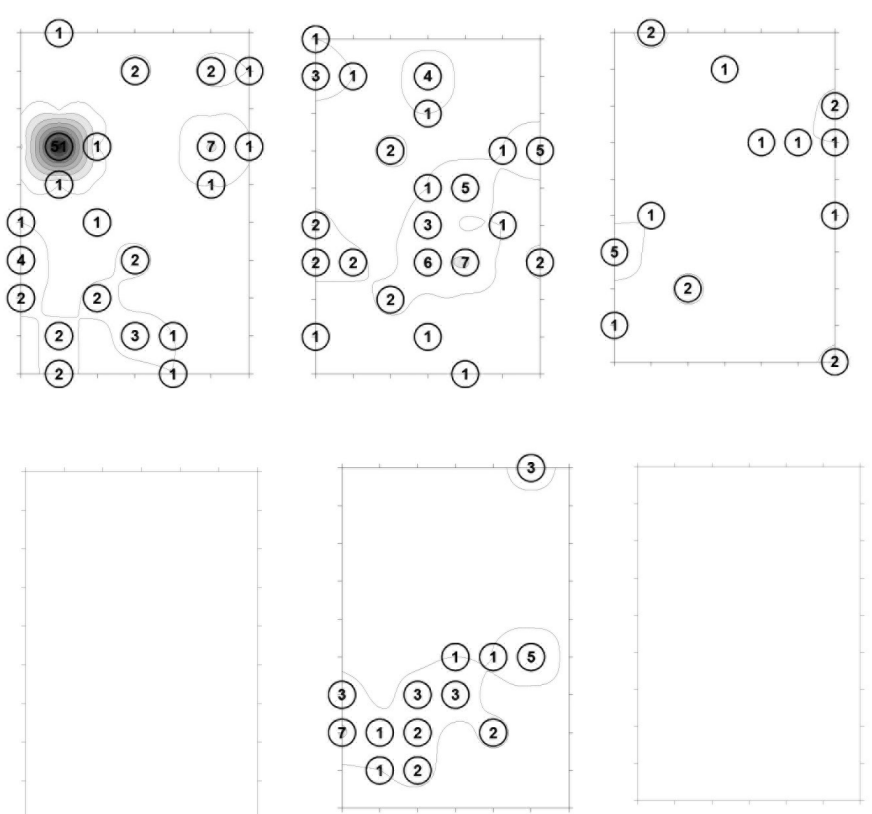

RAJAH 4. Corak taburan ruang-masa di plot A2 (tanah liat) bagi a) Formicinae; b) Ponerinae; c) Myrmicinae; dan d) Aenictinae 
Secara amnya, spesies daripada subfamili Formicidae membuat sarang yang besar pada tanah atau batang pokok hidup atau yang telah mati dan dihuni oleh beribu pekerjanya (Shattuck 2000). Terdapat koloni yang membuat beberapa sarang di kawasan yang berbeza bagi mengelakkan koloni tersebut daripada menghadapai masalah kekurangan sumber makanan serta boleh berpindah ke kawasan lain jika terdapat malapetaka (Dwyer \& Ebert 1994; Ellis \& Robinson 2014). Maka, kelimpahan individu daripada subfamili ini telah mempengaruhi corak taburan ruang masa bagi lokasi setempat yang berbeza.
Ponerinae Pada Plot A1, A2, B1, C1 dan C2, Ponerinae telah menunjukkan corak taburan rawak secara keseluruhan ( $\mathrm{Ia} \leq 1)$. Namun begitu, Plot B2 menunjukkan corak taburan yang rawak (Ia $\leq 1)$ dan juga berkelompok $(\mathrm{Ia}=1.221)$. Hal ini adalah kerana subfamili ini mencari makanan secara bersendirian tanpa mendapat bantuan daripada ahli koloni kerana mereka telah ditugaskan untuk keluar mencari makanan secara meluas (Hölldobler \& Wilson 1990). Spesies daripada subfamili ini mempunyai koloni yang kecil, sarang yang ringkas dan memburu makanan secara bersendirian (Schmidt 2013) dan semua a)

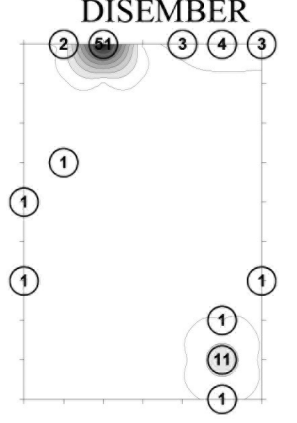

b)

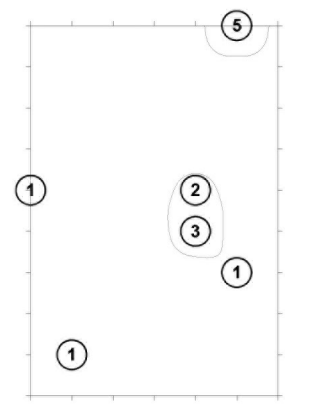

c)

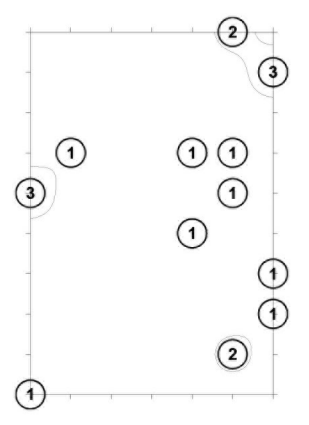

d)

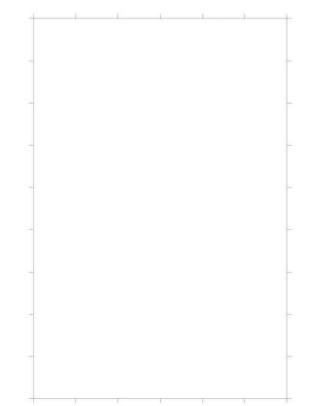

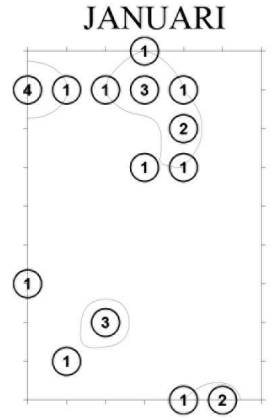
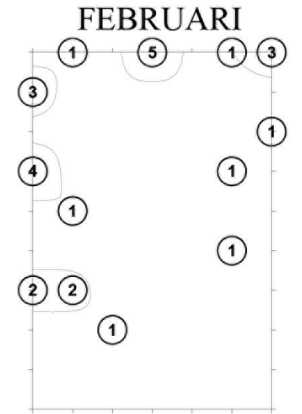

(1) (2)
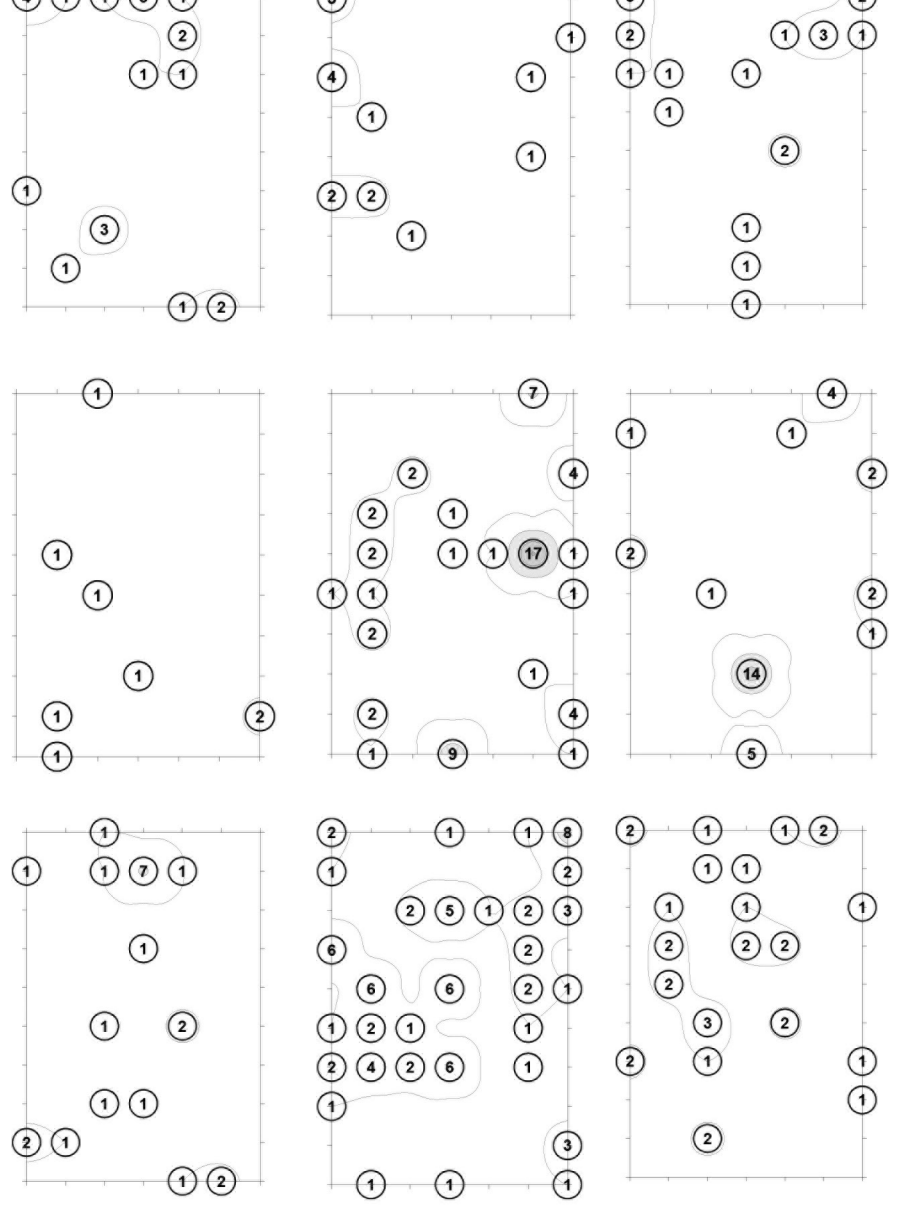

(2) (1) (1) (2)

(2) (2) (2)

(1)

(1) (2)
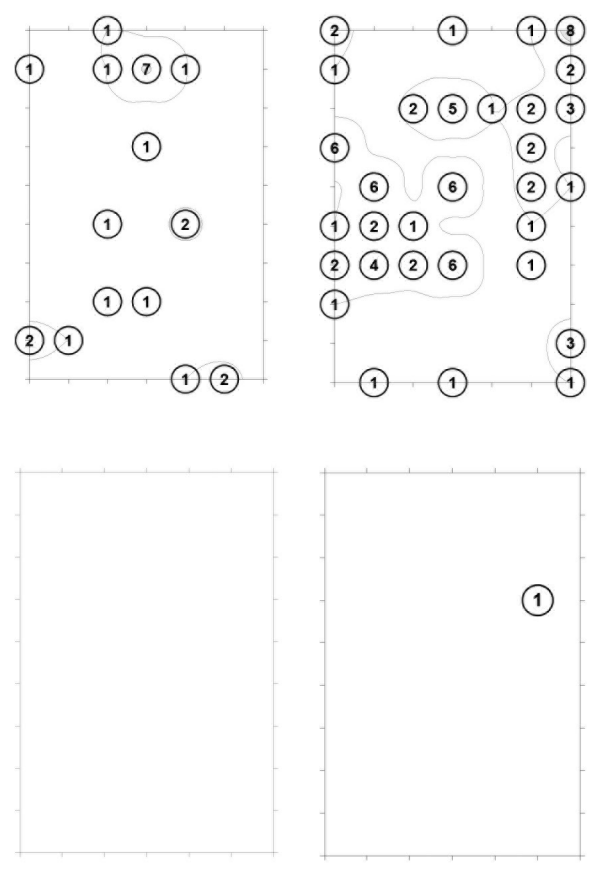

(2)

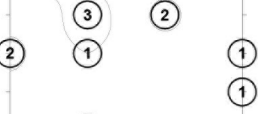

(2)
(2)

\section{(1)}

(1)

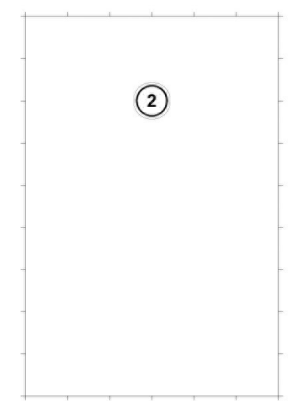

RAJAH 5. Corak taburan ruang-masa di plot B1 (gambut dalam) bagi a) Formicinae; b) Ponerinae; c) Myrmicinae; dan d) Aenictinae 
ini bergantung kepada faktor persekitaran (Detrain \& Deneubourg 2002). Walaupun secara keseluruhan Ponerinae adalah pemangsa, sesetengah spesies daripada subfamili ini memakan lebihan nektar yang dirembeskan oleh kumpulan Lepidoptera (Del-Claro \& Oliveira 1999).

Myrmicinae Pada Plot A1, Myrmicinae menunjukkan corak taburan secara rawak (Ia $>1$ ) dan juga berkelompok. Pada Plot A2 pula, ia menunjukkan corak taburan rawak (Ia $\leq 1)$. Oleh kerana pengelompokan tertumpu pada satu bahagian, maka luang yang terdapat pada plot persampelan adalah signifikan $(\mathrm{Vj}=-1.309 ; p<0.05)$.
Di Plot B1 dan B2, corak taburannya lebih kepada secara rawak (Ia $\leq 1)$. Walaupun terdapat corak taburan secara berkelompok (Ia $>1$ ), tetapi ia adalah tidak signifikan $(p>0.05)$. Di Plot $\mathrm{C} 1$ dan $\mathrm{C} 2$, corak taburannya adalah secara rawak $(\mathrm{Ia} \leq 1)$.

Secara umumnya, Myrmicinae telah menunjukkan corak taburan secara rawak. Individu daripada subfamili ini boleh didapati pada hampir kesemua tempat yang sesuai daripada dalam tanah hinggalah ke atas pokok. Mereka membentuk koloni kecil yang mempunyai lebih kurang 50 individu sehinggalah kepada ribuan individu (Shattuck 2000). Spesies daripada Myrmicinae ini mampu a)

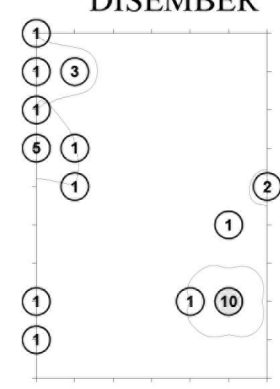

b)

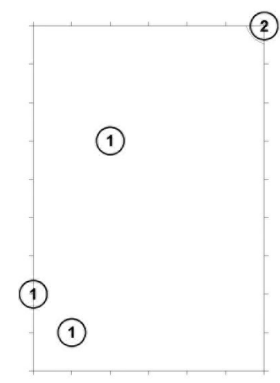

c)

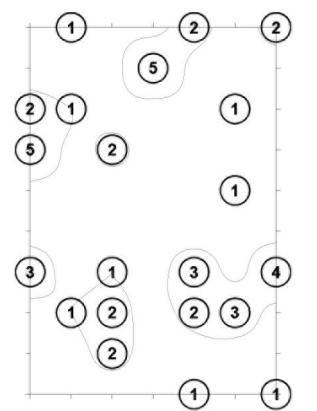

d)

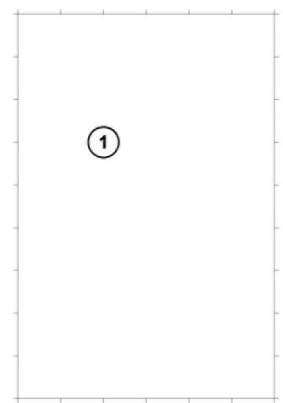

JANUARI

(1)

(1)

(1)

(2)

(1)

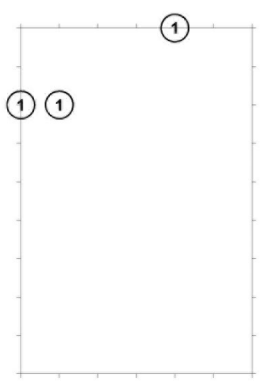

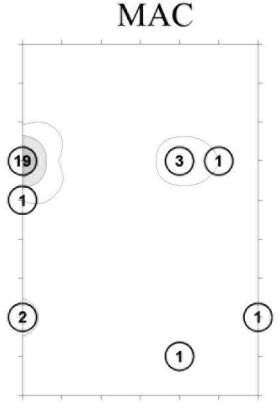

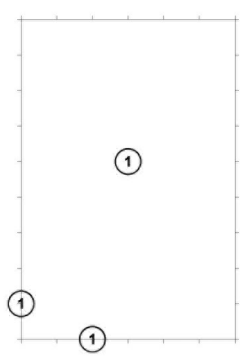

(1)<smiles>CC(C)COC(=O)O</smiles>

(3)

(5) (1)

(4) (1)
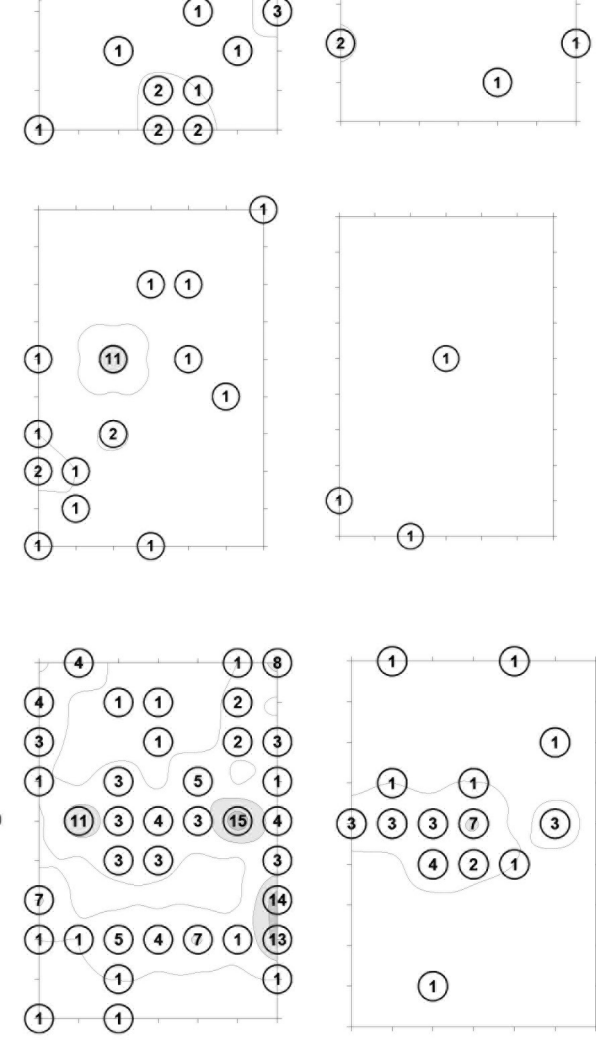

(2)

(1)
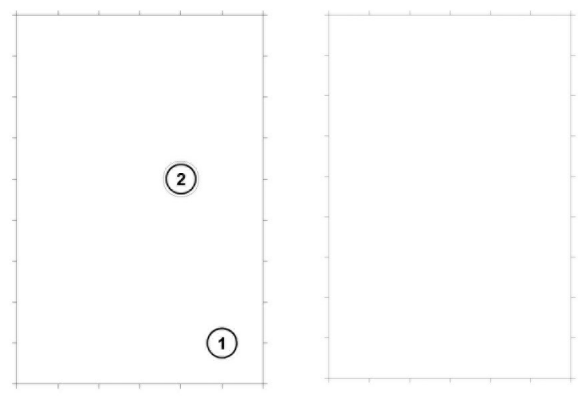

RAJAH 6. Corak taburan ruang-masa di plot B2 (gambut dalam) bagi a) Formicinae; b) Ponerinae; c) Myrmicinae; dan d) Aenictinae 
bersaing dengan koloni yang lebih dominan bagi merebut ruang di sesuatu kawasan (Dejean et al. 2008).

Aenictinae Pada Plot A1, Aenictinae telah menunjukkan corak taburan yang rawak pada bulan Disember 2011 dan Februari 2012. Namun, tidak ada individu yang berjaya ditangkap untuk sesuatu masa. Pada Plot A2 pula, corak taburan adalah secara rawak dan juga berkelompok secara signifikan ( $\mathrm{Ia}=1.449 ; p<0.05)$. Pada Plot B1 dan B2, corak taburannya adalah secara rawak secara keseluruhan walaupun terdapat corak taburan berkelompok. Namun begitu, tiada individu yang berjaya diperoleh untuk sesuatu a)

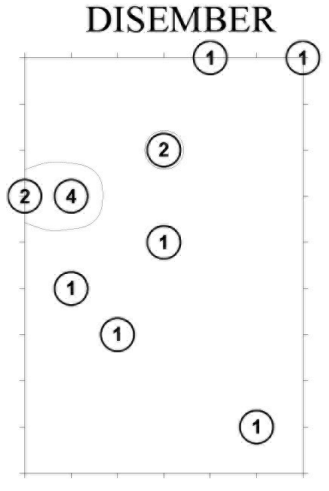

b)

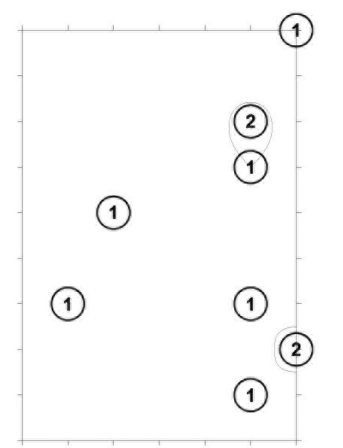

JANUARI
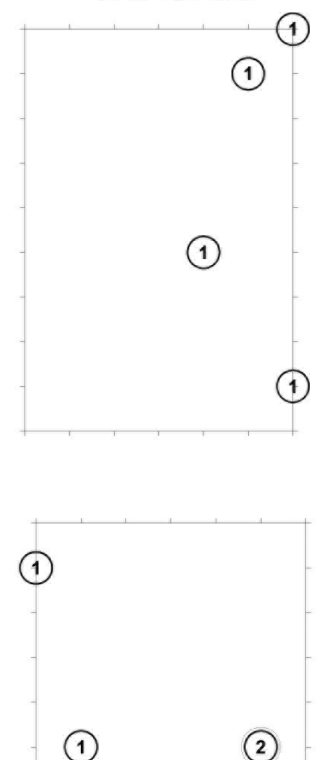

(1)

(1) (2) (1)
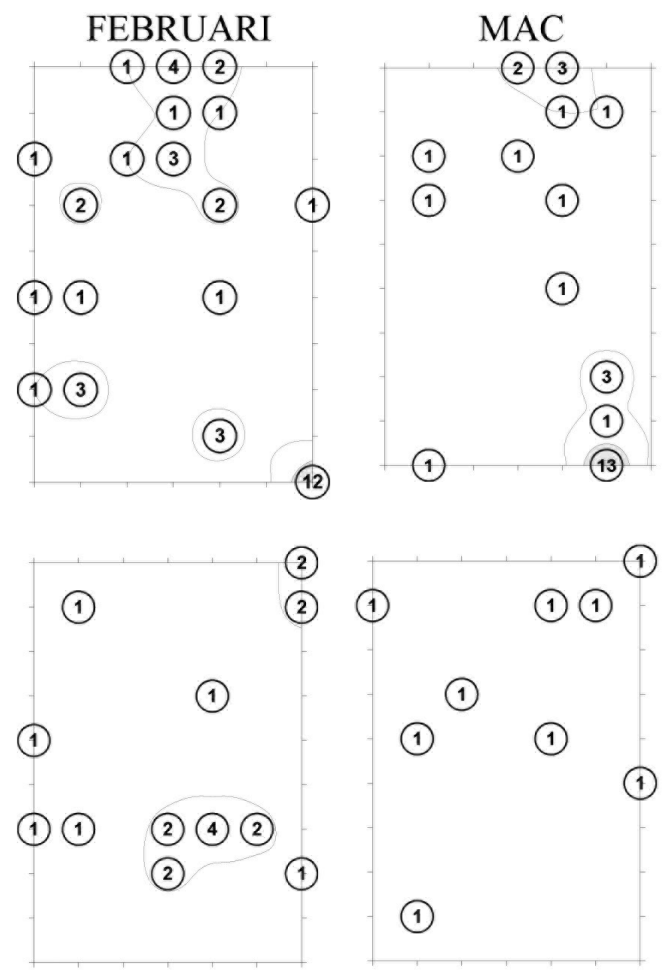

c)

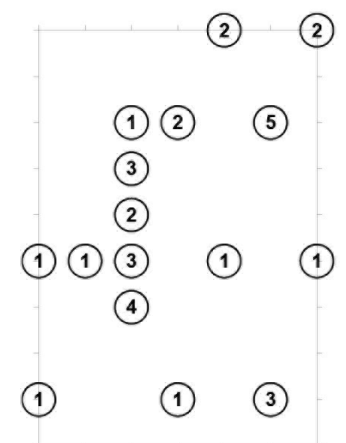

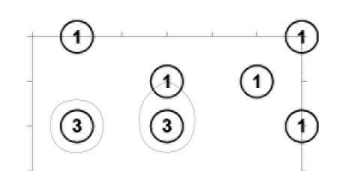

(3)
(1) (2) (1) (1) (1)
(6) (1) (8) (1) (2) (10)

(7) (1) (5) (9) (4)

(3) (3) (1) (1) (2)

(1) (4) (2)

(3) (6) (3)

(3) (2) (3)

(1)

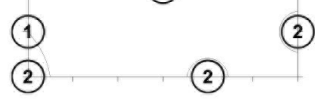

(5) (4)

(2)

(2) (7)

(1) (1)

(3) (1)

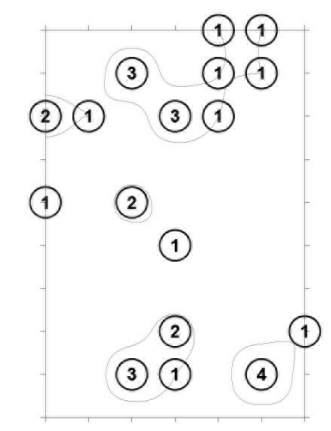

d)
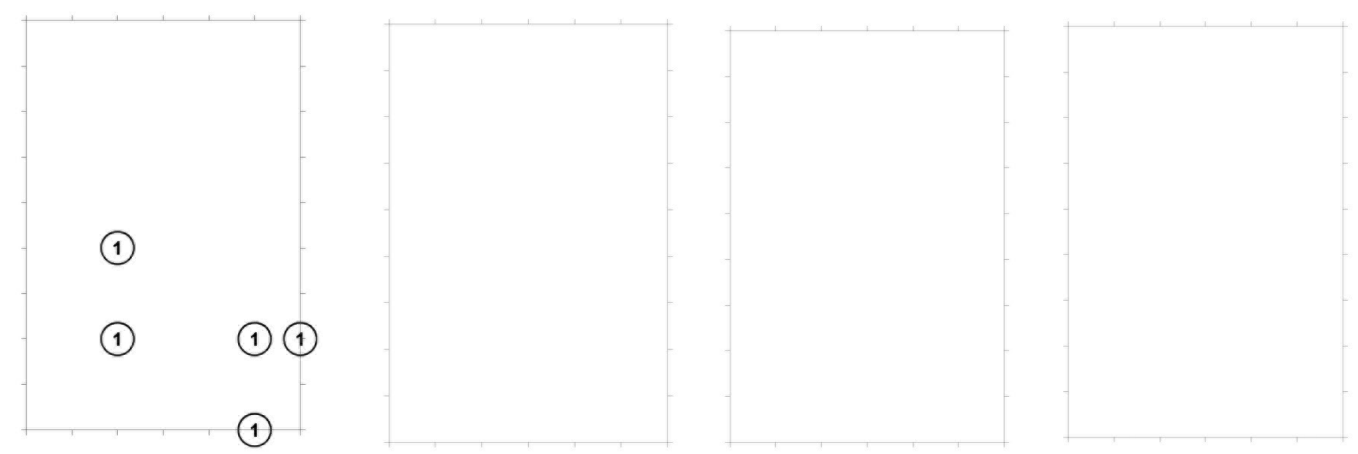

RAJAH 7. Corak taburan ruang-masa di plot C1 (gambut cetek) bagi a) Formicinae; b) Ponerinae; c) Myrmicinae; dan d) Aenictinae 
masa bagi subfamili ini. Di Plot $\mathrm{C} 1$, corak taburannya adalah secara berkelompok secara signifikan $(p<0.05)$. Di Plot C2 pula, corak taburannya adalah secara rawak (Ia $=0.742)$ dan juga berkelompok (Ia $>1 ; p<0.05)$.

Spesies daripada subfamili Aenictinae ini mempunyai ciri yang unik seperti hidup secara nomad dan mencari makanan secara berkumpulan (Gotwald 1995; Staab 2014) Hampir kesemua spesies daripada subfamili ini tidak mempunyai sarang yang kekal dan hidup secara nomad (Hölldobler \& Wilson 1990). Mereka akan sentiasa berjalan dalam radius 100 meter dalam mencari kawasan baru untuk mendapatkan makanan. Koloni daripada subfamili ini a)

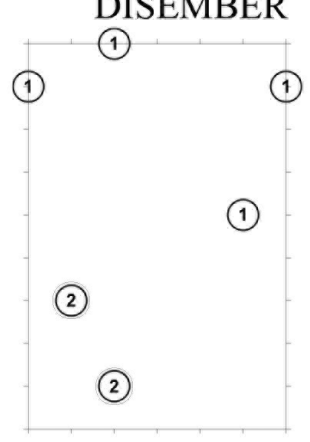

b)

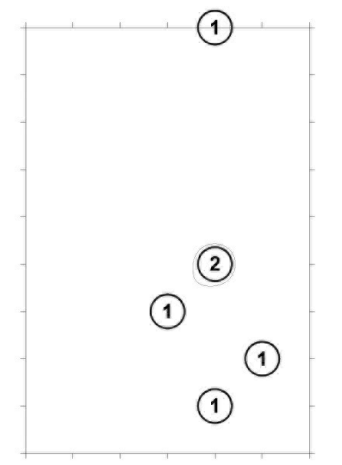

c)

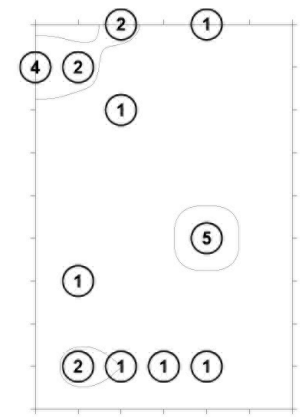

d)

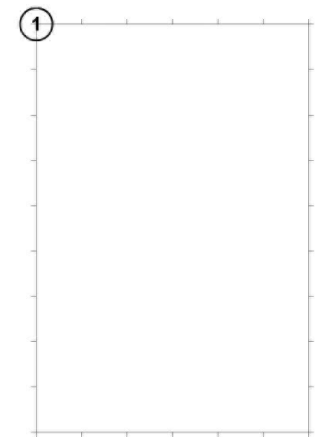

JANUARI

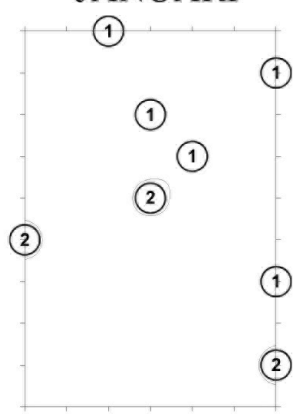

FEBRUARI

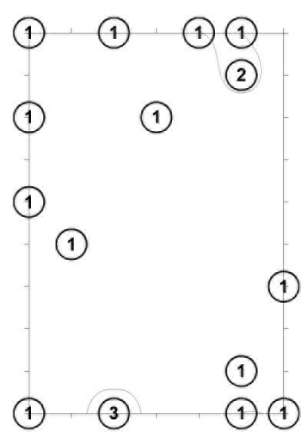

(1) (3) (1)

(2)

(1) (3)

(5)

(1)

(1)

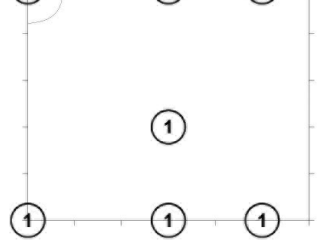

(2)

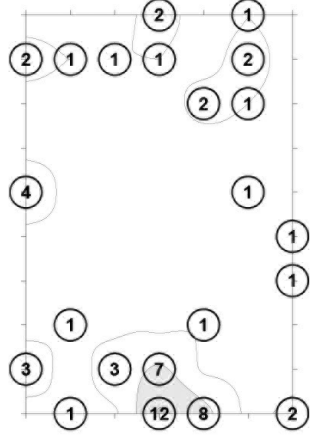

(2)

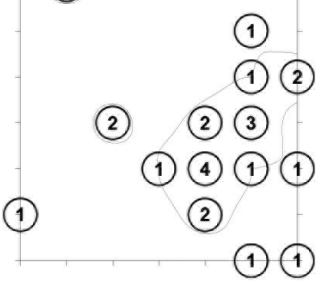

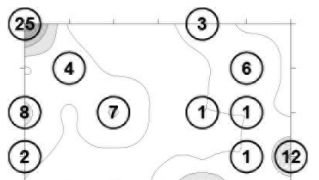
(1) (1)
(5) (1)
(8) (2) (1) (1) (2)
(1) (2) (1)
(4) (5) (10) (7)
(1) (3) (2) (3)
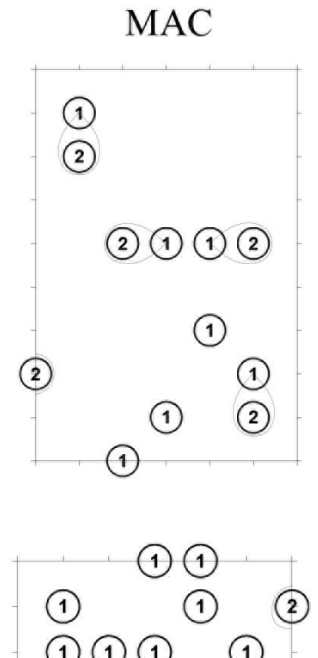

(1)

(1)

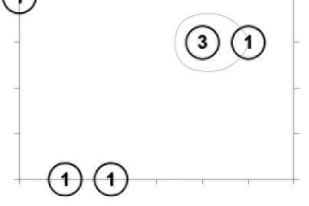
(1) (1) (1) (20)
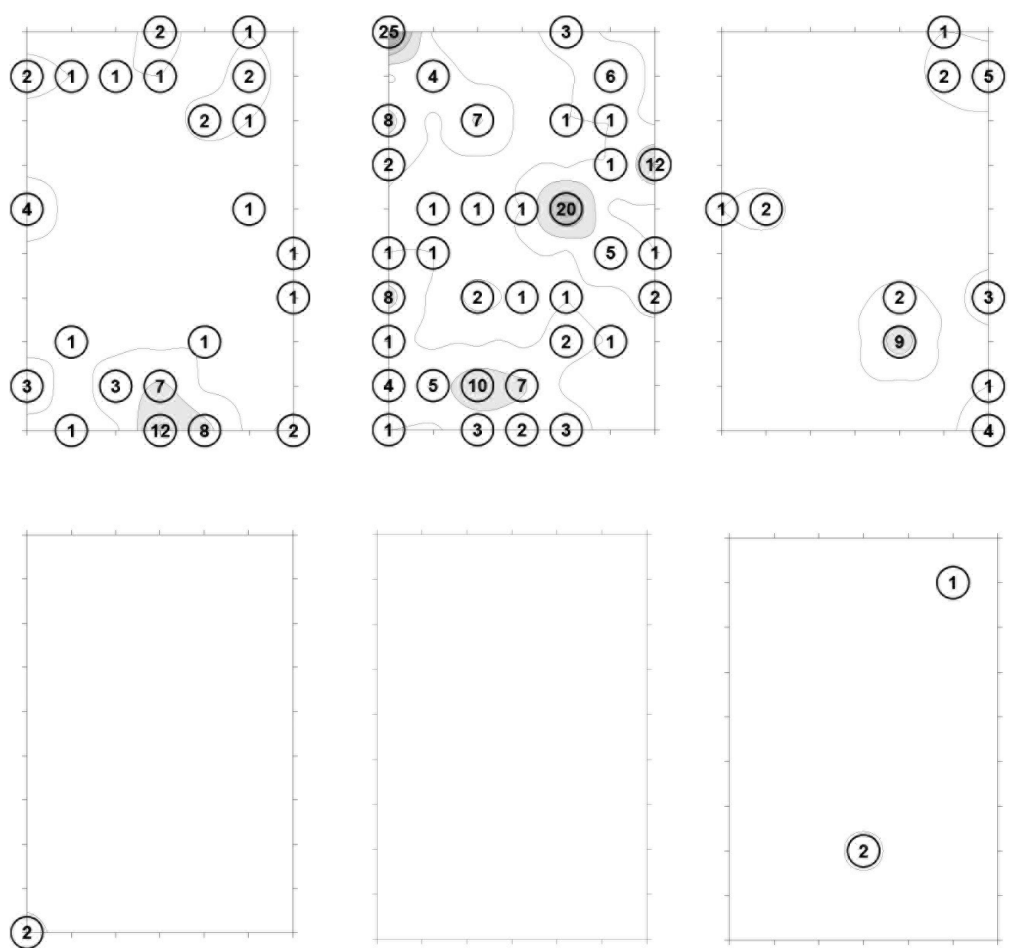

RAJAH 8. Corak taburan ruang-masa di plot C2 (gambut cetek) bagi a) Formicinae; b) Ponerinae; c) Myrmicinae; dan d) Aenictinae 
memaksimumkan tahap penyesuaian mereka terhadap alam sekitar bagi membolehkan mereka menangkap makanan dengan lebih cekap (Franks et al. 2001). Mereka juga memainkan peranan penting dalam dinamik hutan tropika kerana mereka mengawal populasi kebanyakan serangga sosial yang lain (Floren et al. 2014; Gotwald 1995).

\section{KESIMPULAN}

Kajian ini merupakan kajian pertama yang telah memberi gambaran corak taburan ruang-masa setempat bagi semut di ekosistem sawit. Corak taburan ruang-masa semut walaupun dalam skala yang terbatas tetapi telah dapat menunjukkan hubung kait ekologi dan lakuan setiap genus semut yang dicerap pada peringkat subfamili secara kolektif. Pencerapan ekologi kelakuan semut untuk setiap spesies atau kumpulan berfungsi mungkin tidak begitu tepat disebabkan oleh pensampelan yang terhad. Selain itu, keupayaan analisis SADIE dalam mengenal pasti asosiasi ruang-masa antara dua data set bakal memperjelaskan lagi ekologi lakuan dan interaksi dalam kalangan komuniti berfungsi semut. Oleh yang demikian, kajian masa hadapan adalah dicadangkan untuk meneroka dengan lebih mendalam lagi mengenai interaksi antara spesies semut secara eksplisit di ekosistem sawit dan juga untuk memahami fungsi lakuan semut agar dapat dimanipulasikan untuk manfaat pengurusan ekosistem monokultur seperti ladang sawit.

\section{PENGHARGAAN}

Ribuan terima kasih diucapkan kepada Yayasan Pahang Plantation Holdings Sdn. Bhd atas kebenaran menjalankan kajian di ladang sawit YP Plantations. Penghargaan kepada warga Makmal Ekologi Terrestrial, Pusat Sistematik Serangga UKM terutamanya Encik Zabidi, Noor Ain, Faris, Atiqah, Athirah, Shafuraa, Zeti, Aina, Azizil, Juhaida, Azuan, Fatin dan Raja yang membantu sewaktu kerja persampelan dijalankan serta individu yang telah memberikan komen terhadap penambahbaikan kertas ini. Projek ini adalah sebahagian daripada koleksi gandingan untuk projek pemetaan meluas dan sebaran anai-anai yang ditaja oleh Kementerian Pendidikan Tinggi Malaysia melalui Skim Geran Penyelidikan Fundamental (UKM-ST06-FRGS0098-2010).

\section{RUJUKAN}

Bolton, B. 1995. A New General Catalogue of the Ants of the World. Cambridge: Harvard University Press.

Bos, M.M., Tylianakis, J.M., Steffan-Dewenter, I. \& Tscharntke, T. 2008. The invasive yellow crazy ant and the decline of forest ant diversity in Indonesian cacao agroforests. Biological Invasions 10: 1399-1409.

Collingwood, C.A., Agosti, D., Sharaf, M.R. \& van Harten, A. 2011. Order Hymenoptera, family Formicidae. Arthropod Fauna of the UAE 4: 405-474.

Conrad, K.F. \& IACR-Rothamsted. 2001. SADIEShell Version 1.22 .
Davidson, D.W., Cook, S.C. \& Snelling, R.R. 2004. Liquidfeeding performances of ants (Formicidae): Ecological and evolutionary implications. Oecologia 139: 255-266.

Dejean, A., Djieto-Lordon, C., Cereghino, R. \& Leponce, M. 2008. Ontogenic succession and ant mosaic: An empirical approach using pioneer trees. Basic and Applied Ecology 9: 316-323.

Del Toro, I., Ribbons, R.R. \& Pelini, S.L. 2012. The little things that run the world revisited: A review of antmediated ecosystem services and disservices (Hymenoptera: Formicidae). Myrmecological News 17: 133-146.

Del-Claro, K. \& Oliveira, P.S. 1999. Ant-Homoptera interactions in a neotropical savanna: The honeydew-producing treehopper Guayaquila xiphias (Membracidae) and its associated ant fauna on Didymopanax vinosum (Araliaceae). Biotropica 31: 135-144.

Denno, R.F., Gratton, C., Peterson, M.A., Langellotto, G.A., Finke, D.L. \& Huberty,A.F. 2002. Bottom-up forces mediate natural enemy impact in a phytophagous insect community. Ecology 83: 1443-1458.

Detrain, C. \& Deneubourg, J.L. 2002. Complexity of environment and parsimony of decision rules in insect societies. Biological Bulletin 202: 268-274.

Drescher, J., Bluthgen, N. \& Feldhaar, H. 2007. Population structure and intraspecific aggression in the invasive ant species Anoplolepis gracilipes in Malaysian Borneo. Molecular Ecology 16: 1453-1465.

Dunn, R.R., Sanders, N.J., Fitzpatrick, M.C., Agosti, D., Andersen, A.N., Bruhl, C., Cerda, X., Ellison, A.M., Fisher, B.L. \& Gibb, H. 2007. Global ant (Hymenoptera: Formicidae) biodiversity and biogeography-a new database and its possibilities. Myrmecological News 10: 77-83.

Dwyer, P.D. \& Ebert, D.P. 1994. The use of spider silk in the initiation of nest-building by weaver ants (Formicidae: Formicinae: Polyrhachis). Memoirs of the Queensland Museum 37: 115-119.

Ellis, S. \& Robinson, E.J.H. 2014. Polydomy in red wood ants. Insectes Sociaux 61(2): 111-122.

Ellison, A.M., Gotelli, N.J., Dunn, R.R. \& Sanders, N.J. 2011. Counting ants (Hymenoptera: Formicidae): Biodiversity sampling and statistical analysis for myrmecologists. Myrmecological News 15: 13-19.

Errard, C., Delabie, J., Jourdan, H. \& Hefetz, A. 2005. Intercontinental chemical variation in the invasive ant Wasmannia auropunctata (Roger) (Hymenoptera Formicidae): A key to the invasive success of a tramp species. Naturwissenschaften 92: 319-323.

Faszly Rahim. 2008. Community ecology of termite and pest incidences in converted oil palm on peat in Malaysia. Tesis Doktor Falsafah. Universiti Kebangsaan Malaysia (Tidak diterbitkan).

Floren, A., Wetzel, W. \& Staab, M. 2014. The contribution of canopy species to overall ant diversity (Hymenoptera: Formicidae) in temperate and tropical ecosystems. Myrmecological News 19: 65-74.

Foster, W.A., Snaddon, J.L., Turner, E.C., Fayle, T.M., Cockerill, T.D., Farnon Ellwood, M.D., Broad, G.R., Chung, A.Y.C., Eggleton, P., Chey Vun Khen \& Kalsum M. Yusah. 2011. Establishing the evidence base for maintaining biodiversity and ecosystem function on the oil palm landscapes of South East Asia. Philosophical Transactions of the Royal Society 366: 3277-3291. 
Franks, N.R., Sendova-Franks, A.B. \& Anderson, C. 2001. Division of labour within teams of New World and Old World army ants. Animal Behaviour 62(4): 635-642.

Giraud, T., Pedersen, J.S. \& Keller, L. 2002. Evolution of supercolonies: The Argentine ants of southern Europe. Proceedings of the National Academy of Sciences, USA. 99: 6075-6079.

Gotwald, W.H. Jr. 1995. The Army Ants: The Biology of Social Predation. London: Cornell University Press.

Hashimoto, Y. 2003. Identification guide to the ant genera of Borneo. Inventory and Collection. Kota Kinabalu: UMSBBEC Press. hlm. 95-160.

Hoffmann, B.D. \& Hagedorn, H. 2014. Quantification of supercolonial traits in the yellow crazy ant, Anoplolepis gracilipes. Journal of Insect Science 14: 25.

Hölldobler, B. \& Wilson, E.O. 1990. The Ants. Cambridge: The Belknap Press of Harvard University of Massachusetts.

Leonhardt, S.D., Menzel, F., Nehring, V. \& Schmitt, T. 2016. Ecology and evolution of communication in social insects. Cell 164(6): 1277-1287.

Loh, S.K. 2017. The potential of the Malaysian oil palm biomass as a renewable energy source. Energy Conversion and Management 141: 285-298.

Lutinski, J.A., Lutinski, C.J., Guarda, C., Busato, M.A. \& Garcia, F.R. 2017. Richness and structure of ant assemblies (Hymenoptera: Formicidae) in Atlantic forest in southern Brazil. Anais da Academia Brasileira de Ciências 89(4): 2719-2729.

Malaysian Palm Oil Board. 2017. Malaysian Oil Palm Industry Performance 2016 and Prospectsfor2017.http:// www.mpob.gov.my/images/stories/pdf/2017/2017 Dr.KushairiPALMEROS2017.pdf. Diakses pada 11 Ogos 2018.

Mohammed, M., Salmiaton, A., Azlina, W.W., Amran, M.M., Fakhru'l-Razi, A. \& Taufiq-Yap, Y. 2011. Hydrogen rich gas from oil palm biomass as a potential source of renewable energy in Malaysia. Renewable and Sustainable Energy Reviews 15(2): 1258-1270.

Munyai, T.C. \& Foord, S.H. 2015. Temporal patterns of ant diversity across a mountain with climatically contrasting aspects in the tropics of Africa. PLoS ONE 10(3): e0122035.

Perry, J.N., Liebhold, A.M., Rosenberg, M.S., Dungan, J., Miriti, M., Jakomulska, A. \& Citron-Pousty, S. 2002. Illustrations and guidelines for selecting statistical methods for quantifying spatial pattern in ecological data. Ecography 25: 578-600.

Pfeiffer, M., Ho, C.T. \& Teh, C.L. 2008. Exploring arboreal ant community composition and co-occurrence patterns in plantations of oil palm Elaeis guineensis in Borneo and Peninsular Malaysia. Ecography 31: 21-32.

Schmidt, C. 2013. Molecular phylogenetics of ponerine ants (Hymenoptera: Formicidae: Ponerinae). Zootaxa 3647(2): 201-250.

Shattuck, S.O. 2000. Australian Ants: Their Biology and Identification. London: CSIRO Publishing.
Staab, M. 2014. The first observation of honeydew foraging in army ants since 1933: Aenictus hodgsoni Forel, 1901 tending Eutrichosiphum heterotrichum (Raychaudhuri, 1956) in South-East China. Asian Myrmecology 6: 115-118.

Stephens, S.S. \& Wagner, M.R. 2006. Using ground foraging ant (Hymenoptera: Formicidae) functional groups as bioindicators of forest health in northern Arizona ponderosa pine forests. Environmental Entomology 35(4): 937-949.

Sulaiman, F., Abdullah, N., Gerhauser, H. \& Shariff, A. 2011. An outlook of Malaysian energy, oil palm industry and its utilization of wastes as useful resources. Biomass and bioenergy 35(9): 3775-3786.

Wardhaugh, C.W. 2014. The spatial and temporal distributions of arthropods in forest canopies: Uniting disparate patterns with hypotheses for specialisation. Biological Reviews 89: 1021-1041.

Wolkovich, E., Cook, B., McLauchlan, K. \& Davies, T. 2014. Temporal ecology in the Anthropocene. Ecology Letters 17(11): 1365-1379.

Wan Zakhir Wan Nazri, Nur-Athirah Abdullah \&

Farah Nadiah Rosli

Pusat Sistematik Serangga

Fakulti Sains dan Teknologi

Universiti Kebangsaan Malaysia

43600 UKM Bangi, Selangor Darul Ehsan

Malaysia

Dzulhelmi Muhammad Nasir

Unit Entomologi dan Mikrobiologi Gunaan

Bahagian Penyelidikan Biologi

Lembaga Minyak Sawit Malaysia

6 Persiaran Institusi, Bandar Baru Bangi

43000 Kajang, Selangor Darul Ehsan

Malaysia

Bakhtiar Effendi Yahya

Institut Biologi Tropika dan Pemuliharaan

Universiti Malaysia Sabah, Jalan UMS

88400 Kota Kinabalu, Sabah

Malaysia

Faszly Rahim*

Kolej PERMATA Insan

Universiti Sains Islam Malaysia

71800 Bandar Baru Nilai, Negeri Sembilan

Malaysia

*Pengarang untuk surat-menyurat; email: faszly@usim.edu.my

Diserahkan: 13 September 2018

Diterima: $\quad 26$ April 2019 